\title{
Pengembangan mobile learning berbasis android untuk meningkatkan hasil belajar kognitif siswa pada pembelajaran IPS
}

\author{
Eko Prasetyo Utomo \\ SMP Negeri Model Terpadu Bojonegoro \\ Bojonegoro, Indonesia \\ tom.ekop10@gmail.com
}

\begin{abstract}
This study aimed to develop android-based mobile learning and to find out its effectiveness in improving student cognitive learning outcomes in social studies learning. The development process refers to the model of Dick et al. The results of the development are in the form of android-based mobile learning with the main components, namely: 1) introduction to subjects; 2) subject competence; 3) material; and 4) practice questions in the form of quizzes. The feasibility level of the social studies material test is 89.91 percent very feasible category and learning media test is 89.42 percent very feasible category. Sequentially the feasibility level for individual trials was 77.78 percent in the feasible category, the small group trial was 77.92 percent in the feasible category, and the field trial was 83.43 percent for the very feasible category. The product effectiveness test using the t-test showed mobile use. Android-based learning can improve student cognitive learning outcomes in social studies subjects. The media developed has been tested and can be tested on a wider range of subjects for product perfection.
\end{abstract}

Keywords: mobile learning; android; social studies

\begin{abstract}
Abstrak
Tujuan dari penelitian ini untuk mengembangkan mobile learning berbasis android dan mengetahui keefektifannya dalam meningkatkan hasil belajar kognitif siswa dalam pembelajaran IPS. Proses pengembangan mengacu model Dick dkk. Hasil pengembangan berupa Mobile learning berbasis android dengan komponen utama yaitu: 1) pengantar mata pelajaran; 2) kompetensi mata pelajaran; 3) materi; dan 4) latihan soal berupa kuis. Tingkat kelayakan dari uji materi IPS adalah $89,91 \%$ dalam kategori sangat layak, tingkat kelayakan uji media pembelajaran adalah $89,42 \%$ dalam kategori sangat layak. Secara berurutan tingkat kelayakan uji coba perorangan adalah $77,78 \%$ dalam kategori layak, uji coba kelompok kecil adalah 77,92\% dalam kategori layak, dan uji coba lapangan adalah 83,43\% dalam kategori sangat layak Uji keefektifan produk dengan menggunakan uji-t menunjukkan penggunaan mobile learning berbasis android dapat meningkatkan hasil belajar kognitif siswa pada mata pelajaran IPS. Keseluruhan evaluasi formatif menempatkan produk ini dalam kategori sangat layak untuk digunakan dalam pembelajaran IPS. Media yang dikembangkan telah diuji coba dan bisa diuji cobakan pada subyek yang lebih luas untuk kesempurnaan produk.
\end{abstract}

Kata Kunci: mobile learning; android; IPS 


\section{Eko Prasetyo Utomo}

Diterima 27 April 2021, Dipublikasikan April 2021

\section{PENDAHULUAN}

Pendidikan IPS dalam desain kurikulum 2013 bertujuan memberikan penekanan pada cinta tanah air, semangat kebangsaan, patriotisme, pemahaman akan bangsa, dan kegiatan ekonomi masyarakat dalam kerangka wilayah NKRI. Kondisi sebaliknya menunjukkan bahwa sekarang ini pemahaman tentang bangsa, semangat kebangsaan, dan patriotisme generasi muda relatif masih rendah. Secara umum hal tersebut tampak pada tidak hafalnya lagu Indonesia Raya, sila Pancasila, kesulitan mengenal tokoh pahlawan, peristiwa sejarah, dan tidak mengerti batasbatas wilayah Indonesia.

Mata pelajaran IPS salah satu obyek kajiannya yaitu materi sejarah berupaya meningkatkan rasa patriotisme dan semangat kebangsaan di kalangan generasi muda pada usia sekolah. Materi sejarah ini dikembangkan dengan memfokuskan pada nilai-nilai kepahlawanan, nasionalisme, patriotisme, kepahlawanan, kepeloporan hingga keteladanan serta semangat pantang menyerah sebagai landasan pembentukan karakter dan kepribadian siswa (Supardan, 2015).

Objek kajian sejarah dalam mata pelajaran sejarah itu sendiri mempunyai peranan strategis dalam pengembangan kemampuan berpikir historis siswa. Kemampuan ini sangat penting dimiliki siswa, karena dapat meningkatkan jiwa patriotisme, pemahaman tentang bangsa, dan semangat kebangsaan. Lebih lanjut memiliki kemampuan ini dengan baik diharapkan dapat mengembangkan karakter bangsa utamanya nilai nasionalis yang saat ini sedang menjadi fokus utama penguatan pendidikan karakter di sekolah sebagai program wajib dari pemerintah.

Kondisi pandemi covid-19 yaitu siswa belajar dari rumah (BDR) sekolah melalui pembelajaran IPS mempunyai tanggung jawab moral untuk tetap mengembangkan nilai karakter nasionalis pada siswa sebagai generasi muda Indonesia. Tahun ajaran 2019/2020 semester genap SMP Negeri Model Terpadu Bojonegoro dalam kondisi darurat sekolah menyelenggarakan kegiatan belajar jarak jauh dari rumah bagi siswa sehingga penyampaian materi IPS mempunyai hambatan dalam proses pembelajaran. Lebih lanjut hambatanhambatan yang muncul dalam memberikan dampak pada pencapaian hasil belajar siswa untuk ranah kognitif khususnya kelas VIII dengan output nilai rata-rata kelas 61,14 sedangkan KKM 75 pada materi tumbuh dan berkembangnya kesadaran nasional di Indonesia.

Berangkat dari hasil belajar kognitif siswa yang kurang optimal pada masa pandemi covid19, teknik scaffolding salah satu yang bisa digunakan oleh guru dalam upaya meningkatkan mutu pembelajaran di kelas. Teknik ini bisa dikembangkan menjadi sebuah inovasi pembelajaran berupa media pembelajaran dalam bentuk mobile learning yang bisa digunakan oleh siswa untuk belajar mandiri melalui smartphone mereka di rumah. Penggunaan media pembelajaran ini diharapkan mampu membantu siswa dalam belajar secara mandiri sehingga nantinya terjadi peningkatan hasil belajar kognitif siswa (Jabbour, 2014). 


\section{Pengembangan mobile learning berbasis android untuk meningkatkan hasil belajar kognitif siswa pada pembelajaran IPS}

Salah satu gaya belajar abad 21 yang sesuai dengan revolusi industri 4.0 adalah pemanfaatan mobile Learning berbasis android (Calimag et al., 2014; Wahyuningtyas dan Rosita, 2019). Ide dasar dari pengembangan media pembelajaran ini adalah teori konstruktivisme Piaget. Konstruktivisme dalam pembelajaran memberikan siswa kesempatan untuk mengonstruksi sendiri pengetahuan yang mereka dapatkan. Lebih lanjut paham konstruktivisme, belajar merupakan proses pengembangan dari asimilasi, akomodasi, dan ekuilibrasi individu dalam membentuk pengertian berdasarkan pengalaman yang mereka diperoleh (Suparno, 2014). Salah satu ciri konstruktivisme dalam belajar yaitu dalam proses mengonstruksi pengetahuan ditentukan oleh proses pemaknaan oleh individu itu sendiri melalui apa yang mereka lihat, rasakan, dengarkan, dan alami.

Mobile learning berbasis android berupa media audiovisual ini mempunyai komponen utama berupa informasi pendukung tentang mata pelajaran IPS. Siswa dalam mengonstruksi pengetahuan bisa menggunakan media ini sebagai salah satu sumber belajar mereka. Lebih lanjut dengan menggunakan media pembelajaran ini siswa diajak untuk menjadi sejarawan secara virtual melalui sebuah aplikasi android dalam sebuah permainan penjelajahan berupa petualangan periode sejarah dari masa ke masa dengan mengumpulkan informasi peristiwa sejarah.

Di era globalisasi saat ini penting sekali siswa dibekali kemampuan literasi teknologi digital berupa penggunaan teknologi sebagai salah satu alternatif mengakses sumber belajar. Dalam kerangka pendidikan abad 21 siswa diharapkan mampu menggunakan teknologi digital secara tepat untuk mengakses, mengintegrasikan, mengevaluasi dan mengkomunikasikan informasi, serta mengakses dan menggunakan teknologi secara legal (Afandi dan Sajidan, 2018). Untuk itulah dalam kondisi pandemi covid-19 sekarang ini penting kiranya seorang guru mengembangkan sebuah media pembelajaran berbasis literasi teknologi digital sebagai salah satu alternatif media pembelajaran khususnya mata pelajaran IPS untuk belajar anak-anak di rumah. Tujuan dari penelitian ini untuk 1) mengembangkan mobile learning berbasis android dan 2) mengetahui keefektifannya dalam meningkatkan hasil belajar kognitif siswa dalam pembelajaran IPS.

\section{METODE}

Penelitian ini merupakan penelitian pengembangan (R\&D) yaitu menghasilkan produk bidang pembelajaran. Prosedur pengembangan pada penelitian ini menggunakan model Dick dkk (2009). Tahapan dari model ini terdiri dari sembilan langkah, yaitu: 1) mengidentifikasi kompetensi Inti/KI mata pelajaran; 2) mengidentifikasi kompetensi dasar/KD mata pelajaran; 3) menganalisis kemampuan awal dan karakteristik siswa; 4) merumuskan tujuan pembelajaran; 5) mengembangkan instrumen penilaian; 6) mengembangkan strategi pembelajaran; 7) mengembangkan dan memilih bahan ajar; 8) mendesain dan melaksanakan evaluasi formatif; dan 9) merevisi bahan ajar. 
Durasi waktu penelitian dan pengembangan yaitu tiga bulan mulai dilakukan bulan AgustusNovember 2020. Tempat pelaksanaan uji coba dilakukan di SMP Negeri Model Terpadu Bojonegoro. Subyek uji coba meliputi ahli pengembang pembelajaran IPS, ahli pengembang media pembelajaran, dan subyek uji coba yaitu siswa sebagai pengguna.

Populasi penelitian untuk uji coba siswa sebagai pengguna yaitu siswa kelas VIII tahun ajaran 2020/2021 sejumlah 155 anak. Sampel uji coba dipilih berdasarkan purposive sampling dengan prosedur uji coba pengguna melalui tiga tahapan yaitu uji coba perorangan 5 siswa, uji coba kelompok kecil 15 siswa, dan uji coba lapangan 30 siswa. Subyek uji coba dipilih berdasarkan kemampuan awal yang meliputi kemampuan awal rendah, sedang, dan tinggi.

Jenis data dalam penelitian dan pengembangan produk mobile learning berbasis android ini yaitu kualitatif dan kuantitatif. Adapun data kualitatif berupa berupa saran atau masukan untuk perbaikan media yaitu aspek isi materi pembelajaran oleh ahli pengembang pembelajaran IPS meliputi: 1) pengorganisasian materi; 2) relevansi materi; 3) strategi pembelajaran; 4) latihan Soal; 5) bahasa; dan 6) tampilan visual. Untuk aspek media pembelajaran oleh ahli pengembang media pembelajaran meliputi: 1) bahasa; 2) strategi pembelajaran; 3) perangkat lunak; dan 4) visual. Sedangkan data dari sasaran uji coba dalam hal ini siswa meliputi: 1) kualitas tujuan dan isi; 2) kualitas instruksional; dan 3) kualitas teknis (Hakky dkk, 2018).

Data kuantitatif meliputi 1) informasi yang diperoleh dari angket dari ahli pengembang pembelajaran IPS berupa angka persentase kemudian dijelaskan secara deskriptif; 2) informasi yang diperoleh dari angket dari ahli pengembang media pembelajaran IPS berupa angka persentase kemudian dijelaskan secara deskriptif; dan 3) informasi yang diperoleh dari angket uji coba siswa sebagai pengguna 4) tes pengukuran hasil belajar kognitif. Teknik pengumpulan data kualitatif dengan menggunakan angket isian untuk memberikan saran atau masukan. Untuk data kuantitatif, teknik pengumpulan data menggunakan angket skala likert uji kelayakan produk oleh ahli pengembang pembelajaran IPS, ahli pengembang media pembelajaran IPS, dan siswa sebagai pengguna serta tes hasil belajar kognitif siswa.

Teknik analisis data kualitatif berupa saran atau masukan perbaikan produk dianalisis dengan teknik deskriptif untuk selanjutnya dilakukan tindak lanjut berupa perbaikan produk. Untuk data kuantitatif teknik analisis data untuk hasil angket dari ahli pengembang pembelajaran IPS dan ahli pengembang media pembelajaran IPS dan angket uji coba siswa sebagai pengguna dikonversi dalam bentuk persentase untuk menentukan kelayakan mobile learning berbasis android. Kriteria uji kelayakan media hasil pengembangan sebagai berikut (Tabel 1).

Tabel 1. Intrepetasi uji kelayakan

\begin{tabular}{cc}
\hline Skor & Kriteria \\
\hline $0 \%-20 \%$ & Tidak layak \\
$21 \%-40 \%$ & Kurang layak \\
$41 \%-60 \%$ & Cukup layak \\
$61 \%-80 \%$ & Layak \\
$81 \%-100 \%$ & Sangat layak \\
\hline
\end{tabular}

Sumber: Analisis statistik rentang kelas masing-masing kategori data 


\section{Pengembangan mobile learning berbasis android untuk meningkatkan hasil belajar kognitif siswa pada pembelajaran IPS}

Keefektifan produk akhir berupa mobile learning berbasis android dianalisis dilakukan uji statistik dengan desain pra eksperimen one group pre test-post test pada kelompok tunggal. Nilai pre test-post test diperoleh dari nilai tes hasil belajar kogntif sebelum dan sesudah menggunakan mobile learning berbasis android. Nilai pre test-post test selanjutnya dianalisis dengan menggunakan analisis statistik uji-t. Dikatakan efektif apabila setelah dilakukan uji-t terhadap hasil belajar yang diukur dengan menggunakan tes pengetahuan kognitif yaitu thitung lebih besar daripada t tabel.

\section{HASIL DAN PEMBAHASAN}

Pengembangan media pembelajaran IPS berupa mobile learning berbasis android ini untuk membantu siswa dalam mengonstruksi pengetahuan siswa akan materi IPS melalui pengalaman belajar yang bermakna sesuai dengan kebutuhan mereka akan sebuah media belajar mandiri secara efektif, efisien, dan menarik pada kondisi pandemi covid-19 ini. Dalam pembelajaran IPS secara khusus materi sejarah. Dengan menggunakan media pembelajaran yang dekat dengan dunia siswa ini diharapkan dapat membantu siswa keluar dari kejenuhan ketika belajar dari rumah dengan mengajak siswa menjadi sejarawan atau peneliti sejarah. Adapun proses penemuan atau pembaharuan mengacu desain yang dikembangkan oleh Dick, Carey dan Carey (2009) meliputi sembilan tahapan.

Pertama mengidentifikasi tujuan pembelajaran yaitu melakukan analisis kurikulum pada mata pelajaran IPS kurikulum 2013 yaitu analisis kompetensi inti (KI). Dalam hal ini KI yang dianalisis yaitu kelas VIII materi tumbuh dan berkembangnya semangat kebangsaan di Indonesia pada semester genap. Kedua melakukan analisis instruksional yaitu mengidentifikasi kompetensi dasar (KD). Kompetensi dasar yang ingin dicapai dengan penggunaan produk hasil pengembangan ini yaitu di fokuskan pada KD 3 ranah kognitif berupa peningkatan kemampuan hasil belajar kognitif siswa.

Tahap selanjutnya yaitu tahap ketiga melakukan analisis kemampuan awal, gaya belajar, dan karakteristik siswa. Dari hasil dokumentasi daftar hasil belajar kognitif siswa diketahui kemampuan awal siswa pada materi IPS materi ini yaitu nilai rata-rata kelas 61,14 dengan KKM 75. Sedangkan dari hasil analisis angket tentang gaya belajar pada siswa SMP Negeri Model Terpadu Bojonegoro sebanyak 155 anak diketahui bahwa di kelas VIII gaya belajar visual mendominasi sebanyak 121 anak atau 88,06\%, gaya belajar auditory sebanyak 10 anak atau 6,45\%, dan sisanya gaya belajar kinestesis 24 anak atau 15,48\%.

Siswa SMP vila ditinjau dari teori perkembangan kognitif Piaget yaitu berada pada tahap operasional formal (13-15 tahun) yaitu anak-anak mampu dalam merumuskan sebuah alternatif hipotesis permasalahan dan selanjutnya mengecek data untuk menjawab hipotesis hingga akhirnya membuat keputusan yang layak. Materi tumbuh dan berkembangnya semangat kebangsaan di Indonesia merupakan lanjutan dari materi kolonialisme dan imperialisme bangsa barat di Indonesia, sehingga mereka sudah memiliki kemampuan awal tentang keunggulan Indonesia yang menjadi daya tarik bangsa-bangsa barat untuk datang ke wilayah nusantara serta mengetahui kesadaran sebagai bangsa terjajah.

Berdasarkan hasil survei refleksi pembelajaran IPS yang dilakukan oleh guru mata pelajaran IPS menunjukkan hanya 5 dari 30 siswa di kelas yang memberikan jawaban membaca buku di rumah untuk belajar selama masa pandemi covid-19 ini. Berdasarkan data yang telah diuraikan di atas maka dibutuhkan media pembelajaran yang memiliki spesifikasi efektif, efisien, dan 
menarik untuk membantu siswa mengonstruksi pengetahuan mereka melalui kegiatan belajar di rumah.

Keempat yaitu merumuskan tujuan pembelajaran yang meliputi: 1) dengan menggunakan mobile learning berbasis android siswa mampu menyebutkan latar belakang munculnya nasionalisme di Indonesia; dan 2) dengan menggunakan mobile learning berbasis android siswa mampu mendeskripsikan organisasi pergerakan nasional Indonesia. Tujuan pembelajaran penting untuk dirumuskan karena sebagai patokan guru dalam mengembangkan kriteria capaian ketuntasan minimal siswa setelah mengikuti pembelajaran IPS pada materi tersebut.

Untuk mengukur ketercapaian tujuan pembelajaran yang telah dirumuskan, maka selanjutnya pada tahap kelima dilakukan pengembangan instrumen penilaian. Penilaian meliputi tes hasil belajar dan latihan soal atau kuis untuk dikerjakan siswa pada mobile learning berbasis android. Tes hasil belajar dilakukan sebelum dan sesudah pembelajaran untuk mengetahui peningkatan hasil belajar melalui pre test dan post test. Instrumen penilaian yang dikembangkan yaitu ranah kognitif berupa tes pilihan ganda pada materi tumbuh dan berkembangnya semangat kebangsaan.

Tahap keenam yaitu mengembangkan sebuah Rencana Pelaksanaan Pembelajaran (RPP). Pada kegiatan ini guru mengembangkan strategi pembelajaran yang dikembangkan meliputi perpaduan urutan kegiatan pembelajaran, metode, media, dan waktu. Urutan kegiatan pembelajaran dalam RPP mengikuti sintak pembelajaran masa pandemi yaitu 1) guru memberikan bahan materi kepada siswa untuk dipelajari secara mandiri; 2) siswa mempelajari materi secara mandiri; 3) guru bersama siswa melakukan pendalaman materi melalui sebuah diskusi dengan menggunakan media Zoom; 4) siswa menggunakan lembar kerja siswa dalam bentuk bahan ajar cetak yang sudah dikembangkan oleh guru untuk pendalaman materi; dan 5) penilaian dengan menggunakan media google form.

Selanjutnya untuk tahap ketujuh yaitu mengembangkan dan memilih bahan instruksional mata pelajaran IPS kelas VIII kurikulum 2013 yaitu berupa mobile learning berbasis android. Media ini terdiri dari 1) pengantar mata pelajaran; 2) kompetensi mata pelajaran; 3) materi; dan 4) latihan soal berupa kuis. Tampilan dari produk mobile learning berbasis android hasil pengembangan sebagai berikut (Gambar 1).

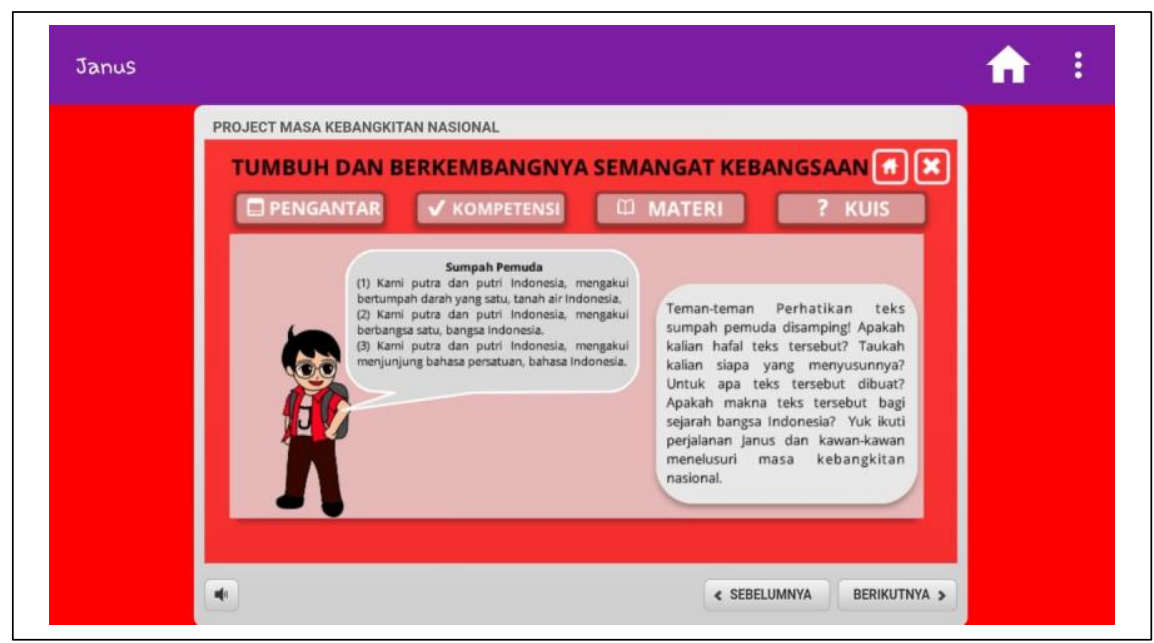

Gambar 1. Tampilan menu utama mobile learning berbasis android 


\section{Pengembangan mobile learning berbasis android untuk meningkatkan hasil belajar kognitif siswa pada pembelajaran IPS}

Mobile learning berbasis android pada mata pelajaran IPS ini merupakan media pembelajaran interaktif yang dikembangkan (by design) untuk siswa dalam proses pendalaman materi secara individu. Cara menggunakan media pembelajaran ini yaitu dengan memasang terlebih dulu aplikasi yang telah selesai dikembangkan pada masing-masing telepon genggam siswa. Setelah berhasil dipasang siswa tinggal menjalankan aplikasi tersebut dengan membaca petunjuk terlebih dulu pada bagian awal layar. Selanjutnya siswa akan diarahkan menuju pada menu utama (home) yang meliputi tombol pengantar, kompetensi, materi, dan kuis. Satu per satu secara berurutan siswa mengakses setiap menu utama yang telah disediakan. Pada akhir menu setlah siswa mengakses pengantar mata pelajaran, kompetensi yang akan dicapai, dan materi pelajaran maka siswa bisa mengerjakan latihan soal berupa kuis dan langsung bisa mengetahui nilai yang diperoleh serta umpan balik secara langsung terkait dengan materi yang disajikan.

Setelah produk mobile learning selesai pada tahap pengembangan tahap terakhir yaitu kedelapan yaitu mendesain dan melaksanakan evaluasi formatif. Kegiatan ini dimaksudkan untuk memperoleh saran dan sekaligus uji validasi dari pakar terhadap produk pengembangan yaitu mobile learning berbasis android. Pada bagian pertama dilakukan uji validasi ahli oleh ahli pengembang pembelajaran IPS dan pengembang media pembelajaran IPS (Tabel 2).

Tabel 2. Hasil Uji Kelayakan Materi IPS

\begin{tabular}{|c|c|c|c|}
\hline No. & Aspek & Nilai $(\%)$ & Kriteria \\
\hline 1. & Pengorganisasian Materi & 88,57 & Sangat layak \\
\hline 2. & Relevansi materi & 96 & Sangat layak \\
\hline 3. & Strategi pembelajaran & 90 & Sangat layak \\
\hline 4. & Latihan Soal & 94,29 & Sangat layak \\
\hline 5. & Bahasa & 90 & Sangat layak \\
\hline 6. & Tampilan visual & 80 & Layak \\
\hline & Nilai rata-rata & 89,81 & Sangat layak \\
\hline
\end{tabular}

Sumber: Analisis data primer 2020

Hasil uji kelayakan materi IPS dari ahli pengembang pembelajaran IPS menunjukkan bahwa tingkat kelayakan aspek pengorganisasian materi adalah 88,57\% dalam kategori sangat layak, tingkat kelayakan relevansi materi adalah $96 \%$ dalam kategori sangat layak, tingkat kelayakn aspek efek strategi pembelajaran adalah $90 \%$ dalam kategori sangat layak, tingkat kelayakan aspek latihan soal adalah 94,29\% dalam kategori sangat layak, tingkat kelayakan aspek bahasa dengan nilai 90\% dalam kategori sangat layak, dan tingkat kelayakn aspek tampilan visual adalah $80 \%$ dalam kategori layak. Secara keseluruhan dari ahli pengembang pembelajaran IPS tingkat kelayakan rata-rata adalah $89,81 \%$, hasil tersebut menunjukkan keseluruhan indikator menempatkan materi yang tersedia dalam mobile learning berbasis android sangat layak.

Selain validasi untuk aspek materi IPS, mobile learning berbasis android ini juga di validasi dari aspek media. Berikut hasil uji kelayakan dari ahli media pembelajaran IPS (Tabel 3).

Tabel 3. Hasil Uji Kelayakan Media

\begin{tabular}{|c|c|c|c|}
\hline No. & Aspek & Nilai $(\%)$ & Kriteria \\
\hline 1. & Perangkat lunak & 96,67 & Sangat layak \\
\hline 2. & Visual & 85 & Sangat layak \\
\hline 3. & Bahasa & 80 & Layak \\
\hline 4. & Strategi pembelajaran & 96 & Sangat layak \\
\hline & Nilai rata-rata & 89,42 & Sangat layak \\
\hline
\end{tabular}

Sumber: Analisis data primer tahun 2020 
Uji kelayakan media dari ahli media menunjukkan tingkat kelayakan aspek perangkat lunak 96,67 dalam kriteria sangat layak, tingkat kelayakan aspek visual adalah 85\% dalam kategori sangat layak, tingkat kelayakan aspek bahasa adalah $80 \%$ dalam kategori layak, dan tingkat kelayakan aspek efek strategi pembelajaran adalah $96 \%$ dalam kategori sangat layak. Secara keseluruhan penilaian dari ahli media tingkat kelayakan rata-rata 89,42\%, hasil tersebut menunjukkan bahwa keseluruhan indikator menempatkan mobile learning berbasis android sangat layak.

Setelah produk memperoleh penilaian kelayakan dari ahli pengembang pembelajaran IPS dan ahli media pembelajaran dan dalam kategori sangat layak maka selanjutnya dilakukan uji coba pengguna yaitu siswa. Pada tahap pertama dilakukan uji coba perorangan sebanyak 5 siswa, kelompok kecil sebanyak 15 siswa, dan lapangan sebanyak 30 siswa. Deskripsi tanggapan siswa berikut ini (Tabel 4).

Tabel 4 Hasil Uji coba perorangan, kelompok kecil dan lapangan

\begin{tabular}{lccc}
\hline \multicolumn{1}{c}{ Indikator } & \multicolumn{3}{c}{ Nilai Uji coba (\%) } \\
\cline { 2 - 4 } & Perorangan & Kelompok kecil & Lapangan \\
\hline Kualitas tujuan dan isi & 80 & 81,33 & 83,33 \\
Kualitas instruktional & 76 & 80 & 81,33 \\
Kualitas teknis & 77,33 & 72,44 & 85,78 \\
Rerata & 77,78 & 77,92 & 83,48 \\
Kriteria & Layak & Layak & Sangat layak \\
\hline
\end{tabular}

Sumber: Analisis data primer tahun 2020

Secara keseluruhan uji coba mobile learning berbasis android hasil pengembangan yaitu tingkat kelayakan uji coba perorangan adalah 77,78\% dalam kategori layak. Tingkat kelayakan untuk uji coba kelompok kecil adalah $77,92 \%$ dalam kategori layak. Tahap akhir tingkat kelayakan uji coba lapangan adalah 83,43\% dalam kategori sangat layak.

Keefektifan produk akhir hasil pengembangan mobile learning berbasis android dilakukan analisis statistik uji-t (tabel 5), untuk melihat efektivitas melalui perbedaan hasil belajar kognitif pre test dan post test pada mata pelajaran IPS materi tumbuh dan berkembangnya semangat kebangsaan di Indonesia diperoleh data sebagai berikut.

Tabel 5. Hasil Pengolahan Nilai Pre test- Post test

\begin{tabular}{ll}
\hline Jumlah siswa & 30 \\
\hline Rerata Nilai Pre test & $1888 \bar{X}=62,93$ \\
\hline Rerata Nilai Post test & $2420 \bar{X}=80,67$ \\
\hline Gain $(D)$ (Post-test Pre-test) & $\sum \mathrm{D}=532$ \\
\hline Gain $^{2}$ & $\sum \mathrm{D}^{2}=20.656$ \\
\hline sig & 0,05 \\
\hline $\mathrm{t}$ hitung & 3,59 \\
\hline $\mathrm{t}$ tabel & 1,699 \\
\hline Keputusan & $\mathrm{H}_{0}$ ditolak
\end{tabular}

Sumber: Analisis data primer tahun 2020

Hasil uji $\mathrm{t}$ dari hasil belajar kognitif siswa menunjukkan bahwa $\mathrm{t}$ hitung $=3,59>$ nilai $\mathrm{t}$ tabel $=1,699$ artinya nilai $\mathrm{t}$ hitung lebih besar dari t tabel. Hasil ini menunjukkan bahwa ada perbedaan signifikan hasil belajar kognitif siswa pada saat pre test dan post test dalam penggunaan mobile learning berbasis android. Hasil ini menunjukkan ada peningkatan hasil 


\section{Pengembangan mobile learning berbasis android untuk meningkatkan hasil belajar kognitif siswa pada pembelajaran IPS}

belajar kognitif siswa pada mata pelajaran IPS materi tumbuh dan berkembangnya semangat kebangsaan di Indonesia. Hasil ini sesuai dengan beberapa penelitian yang telah dilakukan oleh Yektyastuti dan Ikhsan, 2016; Muyaroah dan Fajartia, 2017; Setiadi dan Ghofur, 2020 tentang penggunaan media pembelajaran berbasis android dalam pembelajaran terbukti dapat meningkatkan hasil belajar siswa.

Penggunaan mobile learning berbasis android pada pembelajaran IPS dari catatan lapangan selama proses uji coba diketahui juga meningkatkan minat dan motivasi siswa akan belajar IPS materi tumbuh dan berkembangnya semangat kebangsaan. Hal ini sesuai dengan hasil penelitian yang dilakukan oleh Erlinawati, 2016; Handayani, 2016; Meliana dkk, 2016; Setyadi, 2017; Sinta dkk, 2019; tentang penggunaan media pembelajaran berbasis android dalam pembelajaran terbukti meningkatkan minat dan motivasi belajar siswa. Apalagi dalam masa pandemic covid-19 dengan siswa belajar dari rumah, tentu penggunaan media pembelajaran yang menarik dari mengurangi kejenuhan siswa akan belajar mandiri. Penggunaan mobile learning berbasis android bisa menjadi salah satu alternatif sumber belajar bagi siswa dalam masa pandemic covid-19.

Pada masa pandemic covid-19 dengan aktivitas siswa belajar dari rumah tentu teknologi mempunyai peranan penting dalam pembelajaran terutama menyesuaikan dengan gaya belajar siswa sekarang ini sebagai generasi $\mathrm{Z}$ yang dekat dengan media berbasis teknologi. Hal ini sesuai dengan hasil penelitian yang dilakukan oleh Purnomo dkk, 2016; Akviansah dan Sariyatun, 2020; Absor dkk, 2019 tentang perkembangan teknologi dan digitalisasi media dan sumber belajar bagi siswa generasi Z.

\section{SIMPULAN}

Proses pengembangan mobile learning berbasis android meliputi tahapan: 1) mengidentifikasi kompetensi inti/KI mata pelajaran; 2) menganalisis kompetensi dasar/KD mata pelajaran; 3) menganalisis kemampuan awal, gaya belajar, dan karakteristik siswa; 4) merumuskan tujuan pembelajaran; 5) mengembangkan instrumen penilaian; 6) mengembangkan strategi pembelajaran; 7) mengembangkan dan memilih bahan ajar; 8) mendesain dan melaksanakan evaluasi formatif yang meliputi uji kelayakan oleh ahli pengembang pembelajaran IPS, ahli pengembang media pembelajaran, dan siswa sebagai pengguna; dan 9) merevisi bahan ajar. Hasil pengembangan berupa media pembelajaran dengan bentuk mobile learning berbasis android dengan spesifikasi terdiri komponen: 1) pengantar mata pelajaran; 2) kompetensi mata pelajaran; 3) materi; dan 4) latihan soal berupa kuis. Keefektifan produk hasil pengembangan mobile learning berbasis android dengan menggunakan uji-t menunjukkan bahwa ada perbedaan signifikan hasil belajar kognitif siswa sebelum dan sesudah penggunaan mobile learning berbasis android yaitu terdapat peningkatan hasil belajar kognitif siswa pada mata pelajaran IPS materi tumbuh dan berkembangnya semangat kebangsaan di Indonesia. Penggunaan mobile learning berbasis android seperti produk hasil pengembangan ini sangat sesuai digunakan pada masa pandemi covid-19. Selain itu penggunaan media ini sesuai dengan gaya belajar abad 21 khususnya untuk generasi $\mathrm{Z}$ sesuai dengan tuntutan revolusi industri 4.0. Media pembelajaran ini bisa disempurnakan dan dikembangkan untuk materi IPS yang lain. 


\section{Eko Prasetyo Utomo}

\section{DAFTAR PUSTAKA}

Absor, N.F., Umasih, \& Kurniawati, 2019. Pembelajaran Sejarah di SMK era revolusi industri 4.0: tantangan dan peluang. Jurnal Teori dan Praksis Pembelajaran IPS, 4(2), pp. 59-65.

Afandi dan Sajidan, 2018. Stimulasi Keterampilan Tingkat Tingkat Tinggi- Konsep dan Implementasinya dalam Pembelajaran Abad 21. Surakarta: UNS Press.

Akviansah, M.D \& Sariyatun, 2020. Perpustakaan Maya sebagai Sumber Belajar dan

Penunjang Pembelajaran IPS secara Daring di Era Pandemi COVID-19. Jurnal Teori dan Praksis Pembelajaran IPS, 5(2), pp. 92-102.

Calimag, J.N. et al, 2014. Ubquitous learning environment using android mobile application. International Journal of Research in Engineering \& Technology, 2(2), pp.119-128.

Dick, W., Carey, J., \& Carey, L., 2009. The Systematic Desaign Of Instruction Fourth Edition. New Jersey: Pearson Education Inc.

Erlinawati, N.A., Suherman, U., \& Darmawan, D., 2016. Media Pembelajaran Mobile Learning

Untuk Meningkatkan Motivasi dan Kemampuan Praktikum Mahasiswa STIKES Karsa Husada Garut. PEDAGOGIA : Jurnal Ilmu Pendidikan, 14(2), pp. 298-310.

Handayani, T.S. \& Suharyanto, 2016. Pengembangan Mobile Learning Berbasis Android Sebagai Media Pembelajaran pada Materi Fluida Statis Untuk Meningkatkan Minat Dan Hasil Belajar Ranah Kognitif Peserta Didik. Jurnal Pendidikan Fisika 5(6), pp. 384-389.

Hakky, M.K., Wirasasmita, R.H., \& Uska, M.Z., 2018. Pengembangan Media Pembelajaran Berbasis Android untuk Siswa Kelas X Pada Mata Pelajaran Sistem Operasi. EDUMATIC:Jurnal Pendidikan Informatika, 2(1), pp. 24-33.

Jabbour, K.K., 2014. An Analysis of the effect of mobile learning on Lebanse higher education. Informatics in Education, 13(1), pp. 1-15.

Purnomo, A., Ratnawati, N., \& Aristin, N.F., 2016. Pengembangan Pembelajaran Blended Learning Pada Generasi Z. Jurnal Teori dan Praksis Pembelajaran IPS, 1(1), pp.70-77.

Meliana, A., Hidayat, A., \& Ilyas, 2016. Pengembangan Media Pembelajaran Mobile Learning Berbasis Android untuk Meningkatkan Minat Belajar Siswa Di SMA Plus Al-Ghifari. Jurnal Pendidikan Dan Pembelajaran Ekonomi Akuntansi, 2(2), pp. 91-104.

Muyaroah, S. \& Fajartia, M., 2017. Pengembangan Media Pembelajaran Berbasis Android dengan menggunakan Aplikasi Adobe Flash CS 6 pada Mata Pelajaran Biologi. Innovative Journal of Curriculum and Educational Technology, 6(2), pp. 79-83.

Setiadi, M.E., \& Ghofur, M.A., 2020. Pengembangan Media Pembelajaran Mobile Learning Berbasis Android Dengan Pendekatan Kontekstual Pada Mata Pelajaran Ekonomi Kelas X IPS. Didaktis: Jurnal Pendidikan dan Ilmu Pengetahuan, 20(3), pp. 291-307.

Setyadi, D., 2017. Pengembangan Mobile Learning Berbasis Android sebagai Sarana Berlatih Mengerjakan Soal Matematika. Jurnal Satya Widya, 33(2), pp. 87-92.

Sinta, M.D., Alfiandra, \& Waluyati, S.A., 2019. Pengembangan Media Pembelajaran Mobile Learning Berbasis Masalah Dalam Pembelajaran PPKn Di SMA. Bhineka Tunggal Ika: Kajian Teori dan Praktik PKn, 6(2), pp. 224-231. 
Pengembangan mobile learning berbasis android untuk meningkatkan hasil belajar kognitif siswa pada pembelajaran IPS

Supardan, D., 2015. Pembelajaran Ilmu Pengetahuan Sosial Perspektif Filosofi dan Kurikulum. Jakarta: PT Bumi Aksara.

Suparno, P., 2014. Filsafat Konstruktivisme dalam Pendidikan. Yogjakarta: Kanisius.

Wahyuningtyas, N. \& Rosita, F.A.D., 2019. Pengembangan Multimedia Interaktif Berbasis Android Pada Materi Kehidupan Sosial Masyarakat Indonesia. Jurnal Sejarah, Budaya, dan Pengajarannya, 13(1), pp. 34-41.

Yektyastuti, R \& Ikhsan, J., 2016. Pengembangan Media Pembelajaran Berbasis Android pada Materi Kelarutan untuk Meningkatkan Performa Akademik Peserta Didik SMA. Jurnal Inovasi Pendidikan IPA, 2(1), pp. 88-99. 